Helgoländer wiss. Meeresunters. 20, 576-593 (1970)

\title{
Some factors affecting the growth of prosobranch veligers
}

\author{
M. C. Pilkington and V. Fretter \\ University of Reading; Reading, England
}

EXTRAIT: Sur quelques facteurs intervenant dans la croissance des véligères de Prosobranches. Le vélum des véligères de Prosobranches recueille toutes les particules que ses cils composés peuvent maitriser. Chacune des dix espèces d'algues unicellulaires offertes aux larves de Crepidula fornicata et de Nassarius reticulatus subit l'action mécanique de l'estomac. Sauf pour Chlamydomonas parkeae, que les larves ne réussissent pas à détruire, et pour Pbaeodactylum tricornutum dont les frustules sont perforées, les parois cellulaires sont ramollies ou fragmentées. Les cellules de la glande digestive ingèrent le contenu cellulaire y compris le pigment, mais non les débris des parois. Les pigments sont rejectés ultérieurement; ils retardent le cycle de l'activité glandulaire. La croissance est relativement bonne avec des cellules de Monochrysis lutheri et de Pyramimonas grossii, qui se rompent facilement, et avec Phaeodactylum tricornutum; mais il se forme des boules fécales volumineuses qui peuvent obturer la cavité palléale; les grandes frustules de Phaeodactylum tricornutum entrainent un effet purgatif. Chlamydomonas parkeae, Brachiomonas submarina, Exuviaella pusilla et Olisthodiscus sp. sont de mauvais aliments; les deux dernières sont toxiques pour les larves, spécialement Olisthodiscus sp. Nourries de Cricosphaera ap. carterae les deux espèces présentent une bonne croissance et un développement jusqu'à la métamorphose; il en est de même pour Crepidula fornicata nourrie de Exuviella baltica et de Nassarius reticulatus alimenté avec Dunaliella primolecta. Un aliment convenable détermine un aspect particulier du comportement alimentaire. Il ne semble pas que les larves sélectionnent leur aliment lorsqu'elles reçoivent simultanément deux ou trois espèces d'algues, mais de petites cellules facilement maitrisées par le vélum sont absorbées plus fréquemment que des cellules volumineuses. L'apport occasionnel d'aliments bactériens ne semble causer aucun dommage. Un aliment artificiel (par exemple la farine de blé) permet pendant 5 à 6 jours de conserver les larves et d'obtenir leur croissance. Dans toutes les expériences la température et l'éclairage, dont les fluctuations retentissent sur la croissance des larves, furent maintenus constants. La manipulation des larves se fit à l'aide de pipettes. Dans la mer les détritus organiques doivent constituer un apport alimentaire important.

\section{INTRODUCTION}

The majority of marine prosobranch gastropods in temperate waters have a planktotrophic veliger. Observations on their distribution at inshore stations off Plymouth reveal that during daylight hours they are feeding in the surface waters and, in considerable numbers, well below the compensation depth. The extended velum edged with compound cilia and a food groove leading to the mouth propels the larva 
forwards and simultaneously collects food; the velum and foot are uppermost, the visceral mass below. Organic and inorganic particles are collected. If organic particles are available the stomach is filled rapidly and further intake is regulated while the meal is being digested (FRETTER \& MONTGOMERy 1968). When feeding stops the velum may be partly withdrawn and the larva sinks or it may swim actively to a lower level where it is maintained by the languid beat of the velar cilia (FrETTER 1967).

Food particles collected by the velum are manipulated in the gut by cilia and muscles. Cilia pass them straight along the oesophagus to the ventral chamber of the stomach where they are retained and rotated vigorously against the gastric shield, mixed with digestive juices and subjected to mechanical breakdown. A muscular network surrounding each of the two lobes of the digestive gland effects a rhythmical pumping action, drawing the stomach contents into the lobes, so that the food is brought into direct contact with the ingesting cells of the epithelium, and then expelling them, together with secretion and waste. The food is retained in the ventral chamber for a length of time which may be correlated with its apparent food value to the larva and its accessibility to digestive enzymes. Unwanted remains are later directed by cilia and muscles into the style sac where the rotary action of the cilia aggregates them and mixes them with a viscous secretion. These remains include plant pigments once intimately linked with food and passed with them into the cells of the digestive gland; the pigments are soon excreted to the stomach. The faecal mass is sucked from the style sac into the initial part of the intestine and its passage to the anus is effected mainly by muscles. The faeces are compacted into rods which are usually slow to disintegrate.

In high concentrations of a good food a hungry larva will fill the stomach in a few minutes, and then stop feeding while digestion of the meal is underway. If only inorganic particles are available on which there is no organic scum they are collected rapidly and passed directly to the intestine for egestion. Feeding is continuous. Thus the presence of digestible food in the stomach initiates the digestive processes and clean inorganic matter fails to do this. A similar mechnism is found in Amphioxus lanceolatus in which feeding stops when the gut is filled with utilizable food and is continuous if colloidal graphite is collected (Bone 1961). If sand grains rather than organic particles are collected by Artemia salina the rate of collection is ten times that of plant cells of equivalent size and they are speeded through the gut for egestion (REEvE 1963). Differences in the rate of collection of organic and inorganic particles have not been estimated for veligers.

If food is abundant, particles collected by the velum are rejected from the region of the mouth when the stomach is adequately full. If it is scarce and the rate of collection does not exceed the rate of digestion, feeding is more or less continuous.

In order to study the fate of food particles in the gut and to compare the growth rates and efficiency of different foods it was necessary to formulate experimental conditions under which the larvae would remain healthy and metamorphose. Some indication of the sensitivity of the veligers to external conditions will be given when the standardization of the experimental conditions are discussed.

Studies on the growth of molluscan larvae fed on unicellular algae and bacteria have been concentrated on oysters and clams which are of economic importance. The 
present study on prosobranchs, a group relatively neglected except for the work of Scheltema $(1962,1967)$ and Paulson \& Scheltema (1968), differs from others in that it incorporates such observations on gut contents and faecal waste as may help with an understanding of the relative value of different foods. The larvae of Crepidula fornicata (L.) and Nassarius reticulatus (L.) were used since their egg capsules are readily obtainable and provide an abundance of larvae of known age. The initial average size of healthy larvae was surprisingly uniform in terms of shell length (C. fornicata $0.37-0.40 \mathrm{~mm} ; N$. reticulatus $0.32-0.34 \mathrm{~mm}$ ). Shell length was used to estimate growth. In order to obtain healthy $C$. fornicata only the older capsules from which larvae were about to hatch were taken from the care of the parent. The conditions under which larvae of these two prosobranchs were kept proved successful for other species taken from the plankton.

\section{STANDARDIZATION OF EXPERIMENTAL CONDITIONS}

As soon as the larvae hatched they were placed in filtered sea water in acidcleaned glass containers. Polythene vessels proved harmful. It is essential to keep the bacterial population low otherwise growth is impaired (WALNE 1956a, 1958). The water used for all experiments was collected from outside the Plymouth Breakwater to avoid sewage contamination, and passed through glass filters (pore size $3 \mu$ ) under pressure. Filtering through Oxoid membranes (pore size $0.5-1.0 \mu$ ), a slower process necessitating frequent change of filter, was of no apparent advantage. Fresh membrane-filtered water contained $4.77 \times 10^{6}$ bacteria per $10 \mathrm{ml}$ sample compared with $6.02 \times 10^{6}$ in a glass-filtered sample, but there was no significant difference in their bacterial counts after larvae had been kept in each type of water without food for 3.5 days at $12^{\circ} \mathrm{C}$. There were disadvantages in using water treated with antibiotics. A mixture of sodium penicillin $G$ and streptomycin sulphate (50 I.U. \& 0.05 $\mathrm{mg} / \mathrm{ml}$ ) has been used successfully to control bacteria in cultures of oyster larvae (WALNE 1958), and this was used in preliminary experiments with prosobranch veligers. The treated water contained $4.77 \times 10^{3}$ per $10 \mathrm{ml}$ bacteria if the antibiotic solutions were fresh, but $1.26 \times 10^{6}$ per $10 \mathrm{ml}$ if they were a week old and had been stored under refrigeration to retard deterioration. For effective bacterial control the antibiotic solution must be fresh and renewed with daily water change, especially in view of the fact that deterioration is more rapid once the solution is contaminated with bacteria (MARTINDALE 1967).

The method of water change generally used for the culture of bivalve larvae and used by Scheltema (1962) for larvae of Nassarius obsoletus and N. vibex, involves pouring the water through a coarse filter which retains the larvae. This treatment proved detrimental to growth, and larvae of Crepidula fornicata died after two filtrations. The larvae were therefore transferred to fresh water by means of a pipette. This method, more reliable for growth experiments, is time consuming and imposes a limit on the number of animals used. With large numbers shell measurements can be taken on a limited number of veligers during the course of the experiments and these larvae then cast away. With small numbers this may not be practic- 
able and the larvae must be returned to the experiment. The results of twice weekly measurements on the growth of 2 day old larvae of Nassaritus reticulatus over a period of 3 weeks were compared with those of larvae measured only at the beginning and end of the experiment. Although the latter group consistently grew more than the former the difference was not always significant $(P=0.2$ and 0.1$)$.

The volume of sea water available to the larva under experimental conditions may affect growth. To test this the growth of 20 veligers of Crepidula fornicata in a boiling tube with $30 \mathrm{ml}$ sea water was compared with that of 333 veligers in $500 \mathrm{ml}$ sea water in a beaker; the depth of the water was $8 \mathrm{~cm}$ and $9 \mathrm{~cm}$ respectively. A column of water is essential for the successful functioning of the gut (FRETTER $8 x$ Montgomery 1968). Either Cricosphaera sp. or Exuvialla baltica, at concentrations of $40 \times 10^{3}, 20 \times 10^{3}$ or $2 \times 10^{3} \mathrm{cell} / \mathrm{ml}$, were provided for food, the illumination was constant at 155 lux and the temperature was maintained at $12^{\circ} \mathrm{C}$; the water was renewed twice weekly over the 3 week period. A similar experiment was set up using Nassarius reticulatus veligers. Growth in the larger vessels was better, but in all cases the differences in growth were not significant at the $10 \%$ level. Crepidula fornicata larvae fed with Cricosphaera sp. grew significantly better $(P=0.001)$ in both boiling tube and beaker than with $E$. baltica. This agrees with later results. In experiments which were set up to compare the food values of various algal cultures the smaller volumes of water and numbers of larvae were used.

Veligers grew better in the constant illumination used in the last experiment (155 lux) than in the dark. Moreover, in the dark the mortality of algal cells stimulated the growth of bacterial populations and water needed to be changed at least daily. Larvae under continuous illumination showed better growth than when subjected to alternating $12 \mathrm{~h}$ periods of light and dark. The experiments were therefore carried out under constant illumination from a Mazda daylight strip giving an intensity of 155 lux at the water surface. Care was taken to ensure that all vessels in an experiment were subjected to the same light intensity since growth rate is influenced by intensity (Fig. 1).

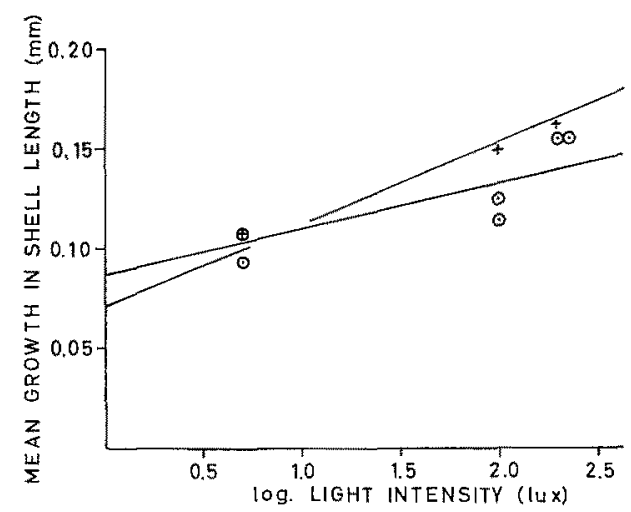

Fig. 1: Nassarius reticulatus. Results of experiments with 2 batches of 20 larvac fed Cricosphaera ap. carterae $\left(20 \times 10^{3}\right.$ cells $\left./ \mathrm{ml}\right)$ for 3 weeks, to show relationship between growth of shell and illumination 
The surface water temperatures off Plymouth have been recorded for Station $\mathrm{E}_{1}$ and ranged from $8.95-10.07^{\circ} \mathrm{C}$ in early spring to $16.15-18.30^{\circ} \mathrm{C}$ in late summer (Armstrong \& Butler 1960a, b, 1962, 1963) over 4 years. Nassarius reticulatus starts to breed in March and Crepidula fornicata in May so $12^{\circ} \mathrm{C}$ was considered a suitable constant temperature for the experiments. Low temperatures reduced larval activity and high temperatures favoured the increase of bacteria. At $8^{\circ} \mathrm{C}$ Crepidula fornicata larvae in both large and small volumes of water collected cells of Cricosphaera sp. and Exuviaella baltica and appeared to digest them, though slowly, but did not grow. At $4^{0} \mathrm{C}$ Nassarius reticulatus larvae did not collect plant cells. For both species a sudden lowering of water temperature from $12^{\circ} \mathrm{C}$ to below $8^{\circ} \mathrm{C}$ caused healthy larvae, actively feeding, to remain stationary with the velum extended, though not fully, and the ciliary beat reduced. They regained full activity when, after $6 \mathrm{~h}$, the temperature was raised.

The water in which the larvae were kept was not agitated or aerated since it was difficult to ensure equality of treatment in the series of experimental vessels and any localized excessive movement of water had a retarding effect on growth.

\section{ALGAL FOODS}

The algal foods (Table 1) were from cultures maintained at Plymouth Laboratory; they were not bacteria free. Old cultures were not used. To compare relative food values each food was given at three concentrations $40 \times 10^{3}, 20 \times 10^{3}$ and $2 \times 10^{3}$ cells $/ \mathrm{ml}$. The last occurs frequently in surface waters of Plymouth Sound; the others may be associated with high density blooms (BAINBRIDGE 1957). The volume of algal culture added to each experimental vessel to give the required concentration was calculated from haemocytometer counts of the stock culture. The value obtained could be only approximate and suffers from the severe limitation that it does not allow for differences in cell size and shape. Differences in cell size have been allowed for (DAvis \& GuILLARD 1958, WALNE 1963) by centrifugation for a standard time in graduated haematocrit tubes. However these determinations are dependent on cell density as well as volume. Table 2 shows that cell density varies greatly in the same culture within a few hours. Such changes in density must affect the distribution of the food in the experimental vessels.

In nature veligers are likely to encounter the higher concentrations of algal cells used in the experiments on growth only briefly. Prolonged access to high concentrations might be harmful. To investigate this Monochrysis lutheri and Pyramimonas grossii were used up to $12 \times 10^{4} \mathrm{cells} / \mathrm{ml}$ and Cricosphaera ap. carterae $60 \times 10^{3}$ cells/ml.

KORRINGA (1951), working on larvae of Ostrea edulis, suggested that toxic concentrations of metabolites are manifest if there are more than 5,000 flagellates $/ \mathrm{ml}$. IMAI \& HATANARA (1949) working with larvae of Crassostrea gigas kept the concentration of Monas sp. below $1 \times 10^{3}-2 \times 10^{3}$ cells/ml. These authors had a maximal concentration of only $2 \times 10^{2}$ larvae/litre. The concentration used in the present experiments is of the order of $7 \times 10^{2}$ litre. WALNE (1956b) on the other 
Table 1

Cultures used for food. Culture numbers refer to the Plymouth collection. The approximate size of the cells is in brackets

\begin{tabular}{|c|c|c|}
\hline Order & $\begin{array}{l}\text { Culture } \\
\text { number }\end{array}$ & Species \\
\hline Dinophyceae & $\begin{array}{r}28 \\
184\end{array}$ & $\begin{array}{l}\text { Exuviaella baltica Loнm }(9-15 \mu) \\
\text { Exuviaella pusilla J. ScHILER }(8-10 \mu)\end{array}$ \\
\hline Haptophyceae & 156 & $\begin{array}{l}\text { Cricosphaera ap. carterae (BraARud et FagerL.) } \\
\text { BraARUd }(10-18 \mu)\end{array}$ \\
\hline Chrysophyceae & 75 & Monochrysis lutheri Droop $(6-10 \times 2-3 \mu)$ \\
\hline Xanthophyceae & 239 & Olisthodiscus sp. $(10-15 \mu)$ \\
\hline Prasinophyceae & 78 & Pyramimonas grossii PARKE $(5.5-8 \times 4.5-5.5 \mu)$ \\
\hline Chlorophyceae & $\begin{array}{r}81 \\
404 \\
285\end{array}$ & $\begin{array}{l}\text { Dunaliella primolecta BuTCH. }(5-10 \mu) \\
\text { Bracbiomonas submarina BoHLIN var. pulsifera Droop } \\
\quad(8 \times 20 \mu) \\
\text { Chlamydomonas parkeae ETTL }(3-8 \mu)\end{array}$ \\
\hline Bacillariophyceae & 100 & Phaeodactylum tricornutum BoHLIN $(8-35 \mu)$ \\
\hline
\end{tabular}

Table 2

Volume of cells deposited by centrifugation for $15 \mathrm{~min}$ at 250 R.P.M. at different times of day

\begin{tabular}{|c|c|c|c|c|}
\hline Alga & 11.00 & $\begin{array}{c}\text { ae of } \mathrm{ce} \\
12.30\end{array}$ & $\begin{array}{l}\text { ted in } \mathrm{ml} \text { at } \\
14.30\end{array}$ & 17.30 \\
\hline $\begin{array}{l}\text { Exuviaella baltica } \\
\text { Olisthodiscus sp. } \\
\text { Cricosphaera ap. carterae } \\
\text { Bracbiomonas submarina }\end{array}$ & $\begin{array}{l}0.0 \\
0.0 \\
0.008 \\
0.005\end{array}$ & 0.01 & $\begin{array}{l}0.0 \\
0.006 \\
0.008 \\
0.008\end{array}$ & $\begin{array}{l}0.0 \\
0.01 \\
0.014 \\
0.005\end{array}$ \\
\hline
\end{tabular}

hand, had a concentration of $5 \times 10^{3}$ larvae/litre and found that while the optimal concentration varied with the species of flagellate, none of the utilizable species gave toxic effects up to $15 \times 10^{3} \mathrm{cells} / \mathrm{ml}$ and for certain species up to $25 \times 10^{3} / \mathrm{ml}$. This may be correlated with the larger number of larvae utilizing the food.

\section{GROWTH WITH ALGAL FOODS}

Increase in shell length of Crepidula fornicata veligers over 3-4.5 week periods was used to demonstrate the relative food values of the 10 algal species. The most vigorous larvae were selected $24 \mathrm{~h}$ after hatching and 20 were placed in each of a series of boiling tubes containing $30 \mathrm{ml}$ filtered sea water. The tubes were covered with perforated parafilm, to reduce aerial bacterial contamination, as soon as the algal cells had been added. Similar experiments were set up with Nassarius reticulatus veligers and a selected number of algal cultures, and mixed cultures were given to 
both species of veliger. The larvae fed vigorously from the beginning of the experiments and all species of algae were ingested. Shell measurements were recorded twice weekly when water and food were renewed and an average of these measurements was used to estimate the relative growth with the different foods. Experiments conducted over 3 breeding seasons showed considerable uniformity of results except for Crepidula fornicata collected from the Plymouth area in 1967. Larvae which hatched over the breeding period (May-September) took up to 4 days to deplete the yolk store as compared with $24 \mathrm{~h}$ in larvae from the same areas in 1966 and 1968. Although all larvae were kept under identical conditions growth in the 1967 brood was generally poor and this, together with indications of a softening shell in an exceptionally large number of individuals 14 days old, was a sign of an unhealthy stock. This season's results for Crepidula fornicata were discarded.

Mean growth in shell length over the whole period of the experiment are given as histograms (Fig. 2). These histograms express the results of single experiments with Crepidula fornicata (a, 1966; c, 1968) and Nassarius reticulatus (b and $d$, 1967). Important differences in results from other experiments are referred to later. The larval life of C. fornicata is about 5 weeks (CHIPPER fIeld 1951), that is shorter than that of $N$. reticulatus which under laboratory conditions is up to 2 months (LeBour 1931). The larvae of $C$. fornicata which grew well were kept under the same conditions after the experimental period to see whether with such a limited diet, and no substratum other than the glass surface, metamorphosis occurred.

\section{Single algal cultures}

With each experiment a batch of 20 unfed veligers served as controls. They lived an average of 3 weeks. Their increase in shell length was probably due to the utilization of remaining food reserves and organic matter, including bacteria in the water. Unfed larvae kept in water treated with antibiotics grew less. The histograms show that certain cultures promoted little growth and were either lethal or of no food value so that the larvae starved. Olisthodiscus sp. inhibited growth of veligers of Nassarius reticulatus at the 2 highest concentrations and they died within 10 days. In the lowest concentration they survived another week, but had grown only as much as the controls. This was the only concentration at which Crepidula fornicata survived to the end of the experiment, though the larvae in the other two grew to twice the size of the controls. These algal cells are toxic to the veligers and although the larvae of Crepidula fornicata continued to eat and grow at the lowest concentration they died 10 days after the end of the experimental period. Larvae also died before the end of the experiment when given Exuviaella pusilla. Observations on stomach contents showed that whereas Olisthodiscus sp. fragmented moderately easily, the cells of E. pusilla needed a more violent mechanical action before their contents were available for digestion. The food promoted more growth in $N$. reticulatus than in $C$. fornicata. All larvae of $N$. reticulatus, and those of $C$. fornicata in the highest concentration of the alga, died in 3 weeks; the rest of the larvae were unhealthy and died a few days after the end of the experiment. Chlamydomonas parkeae and Brachiomonas submarina 
were also poor foods, but had no toxic effects, and larvae taken from them after a week and given better foods thrived; this did not hold for Olisthodiscus sp.

Cricosphaera ap. carterae was the best food for both species especially at the higher concentrations. The poor growth of Crepidula fornicata at the lowest did not appear to be due to periods of food depletion due to only twice weekly renewal, for larvae given daily renewal of algal cells did not show appreciable increase in growth. There is a tendency for these algal cells, and the large cells of Bracbiomonas submarina to settle on the bottom of the tube and become less accessible to the veliger, which,

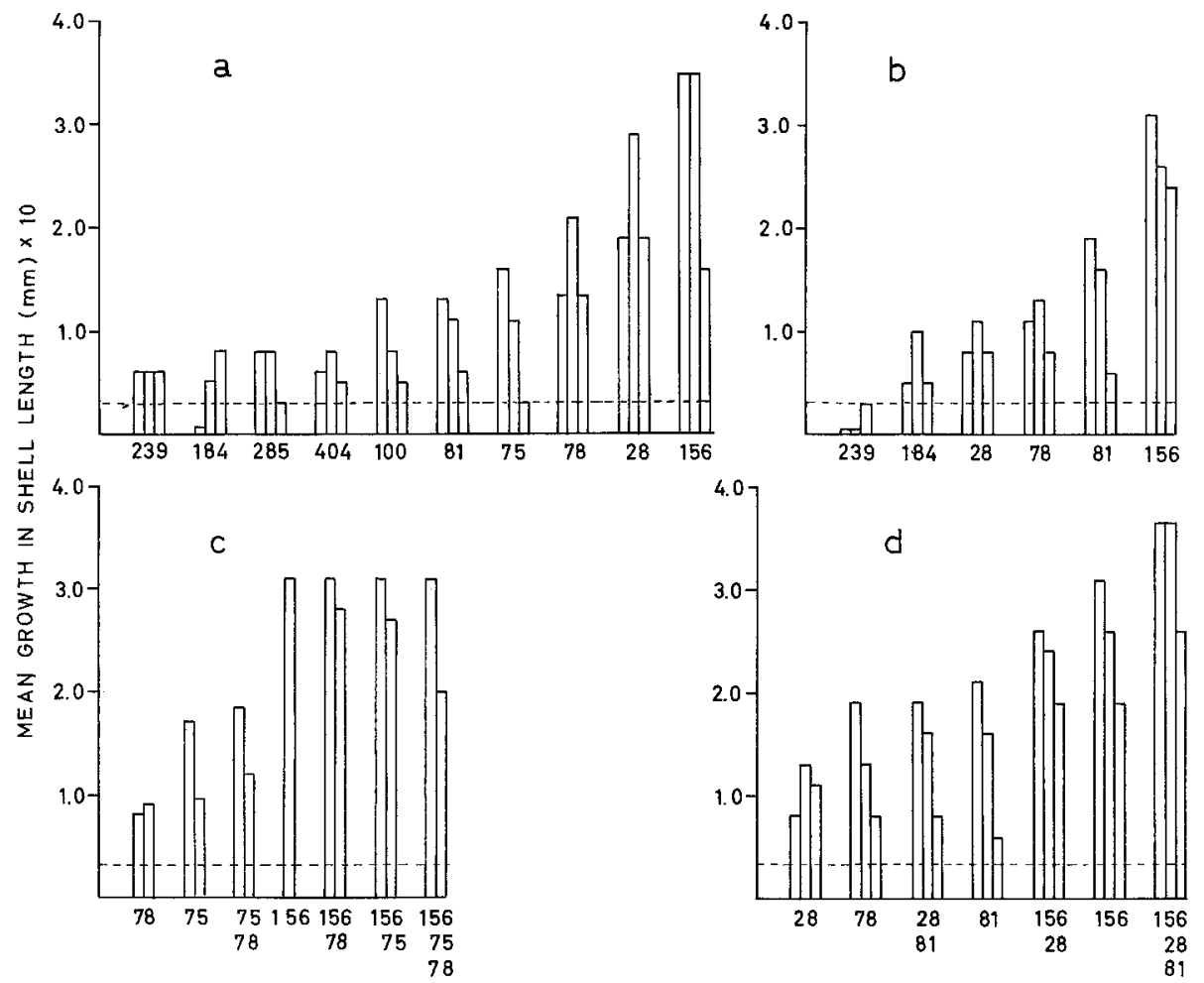

Fig. 2: Mean growth in shell length of veligers of Crepidula fornicata and Nassarius reticulatus fed on single or mixed algal cultures. Broken line indicates shell length of unfed larvae. The numbers refer to Plymouth cultures, and the 3 columns above each indicate growth at $40 \times 10^{3}$ (left), $20 \times 10^{3}$ (middle) and $2 \times 10^{3}$ (right) cells $/ \mathrm{ml}$. Where there are only 2 columns the lowest of the three concentrations was not used, and where only one the highest was used. (a) C. fornicata, fed on single algal cultures 4 weeks; (b) $N$. reticulatus, fed on single algal cultures 4 weeks; (c) C. fornicata, fed on single and mixed algal cultures 3 weeks; $(d) N$. reticulatus, fed on single and mixed algal cultures $4^{1 / 2}$ weeks

however, will attempt to sweep them up with the velum. Exuviaella baltica was good for Crepidula fornicata and in some experiments the larvae grew as well with this food at a concentration of $20 \times 10^{3}$ cells $/ \mathrm{ml}$ as with Cricosphaera ap. carterae. This was always the optimal concentration for E. baltica. The consistently poor value of 
this food to Nassarius reticulatus and the greater value of Dunaliella primolecta may be indicative of the differences in food requirements of the two species of veliger.

Crepidula fornicata reached the swimming-crawling stage after 40 days feeding on Exuviaella baltica at the optimal concentrations, and also at approximately the same time in the two higher concentrations of Cricosphaera ap. carterae. Larvae eventually metamorphosed, though the swimming-crawling stage was unusually prolonged, presumably through lack of a suitable substratum.

In other experiments the two small-celled algae Monocbrysis lutheri and Pyramimonas grossii were given to Crepidula fornicata larvae at the two higher concentrations and 2 others, $80 \times 10^{3}$ and $12 \times 10^{4}$ cells $/ \mathrm{ml}$, to test the effect of high density on growth. The results (Tab. 3) were compared with those from larvae fed with Cricosphaera ap. carterae, the maximum concentration of which was $60 \times 10^{3} \mathrm{cells} / \mathrm{ml}$. All the larvae remained healthy.

Table 3

Mean growth increments in shell length of 10 veligers of Crepidula fornicata in high concentrations of 3 algal foods over a period of 3 weeks

\begin{tabular}{|ccc|}
\hline Species & $\begin{array}{c}\text { Concentration } \\
(\mathrm{cells} / \mathrm{ml})\end{array}$ & $\begin{array}{c}\text { Growth } \\
(\mu)\end{array}$ \\
\hline Pyramimonas grossii & $20 \times 10^{3}$ & 80 \\
& $40 \times 10^{3}$ & 80 \\
& $80 \times 10^{3}$ & 70 \\
& $12 \times 10^{4}$ & 50 \\
& $20 \times 10^{3}$ & 80 \\
Monochrysis lutheri & $40 \times 10^{3}$ & 90 \\
& $80 \times 10^{3}$ & 120 \\
& $12 \times 10^{4}$ & 170 \\
& $20 \times 10^{3}$ & 120 \\
& $40 \times 10^{3}$ & 140 \\
& $60 \times 10^{3}$ & 180 \\
\hline
\end{tabular}

Increase in the number of available cells of Monochrysis lutheri and Cricosphaera ap. carterae resulted in increase in growth. At the highest concentration of $M$. lutheri growth approached that at the highest concentration of $C$. ap. carterae. In contrast the two lower concentrations of Pyramimonas grossii were the best and growth decreased in the two higher. These experiments were carried out at the end of the breeding season and this may account for the fact that growth increase in the best food, C. ap. carterae, was considerably less than in previous experiments.

The food value of Monochrysis lutheri and Pyramimonas grossii varied from experiment to experiment at lower concentrations. They are both moderately good foods but sometimes one is better and sometimes the other; a constant factor is that growth is increased with the concentration in the former and decreased in the latter. Variations in their food value may be due to some differences in the cultures. 


\section{Mixed algal cultures}

Cells of more than one species of alga were mixed in equal proportions and the combined concentrations were $40 \times 10^{3}, 20 \times 10^{3}$ or $2 \times 10^{3}$ cells $/ \mathrm{ml}$. The numbers of food cells available to the larvae were thus comparable to those in previous experiments; in some experiments only the two higher concentrations were used. The results of feeding larvae with Cricosphaera ap. carterae and either of the 2 algae which had some lethal effect, Olistbodiscus sp. and Exuviaella pusilla, showed that the retardation of growth and toxicity caused by Olisthodiscus sp. was still evident in both species of veliger, but there was less evidence of $E$. pusilla being detrimental. In the mixture with E. pusilla the growth of Nassarius reticulatus was improved and the larvae died only in the highest of the 3 concentrations. Results of other experiments are shown in Figure 2, $\mathrm{c}$ and d.

Crepidula fornicata larvae which were fed on Cricosphaera ap. carterae mixed with a poorer food, either Monochrysis lutheri or Pyramimonas grossii, at a concentration of $40 \times 10^{3}$ cells $/ \mathrm{ml}$, grew as well as with Cricosphaera ap. carterae alone at this concentration. This suggests that they were feeding selectively, a phenomenon described by PAulson \& Scheltema (1968) for the larvae of Nassarius obsoletus. However direct observation showed that cells of each alga were ingested and broken down in the stomach. The smaller cells of Monochrysis lutheri and Pyramimonas grossii were ingested in greater numbers than Cricosphaera ap. carterae in accordance with the ease with which the velar cilia manipulated them. The cells of $C$. ap. carterae and Exuviaella baltica are more closely related in shape and size and about the same number of these were ingested when they were given together. E. baltica is a poor food for Nassarius reticulatus, but in this mixture growth was considerably improved at the three concentrations. A mixture of these two algae and Dunaliella primolecta produced the best growth in $N$. reticulatus.

The results of feeding with mixture of 2 algae not including Cricosphaera ap. carterae - Pyramimonas grossii and Monochrysis lutheri, or Dunaliella primolecta and Exuviaella baltica - show that growth is better than when the poorer food of each pair is given singly.

\section{BACTERIAL FOODS}

Experiments with bivalves have shown the deleterious effects of bacteria as foods when larvae are exposed to them for a few days (Davis 1953, Guillard 1959). The fate of bacteria in the gut of a veliger has not been studied, nor the effect of exposing the larva to bacterial suspensions for brief periods of time. To carry out observations on these, experiments were set up as for algal cultures.

Agar cultures of 8 strains of Gram-negative bacteria from the inshore surface water of Cardigan Bay were supplied by Dr. M. Rhodes and Mr. D. WYNN-WILLIAMS and 5 were provisionally identified. According to the test methods given by SHEwAN (1963) 3 were Vibrio spp. (K4B, K12B, K27A), all motile, and 2 were Flavobacterium spp. (K4A, K28). Another strain was very similar to Pseudobacterium lateri- 
ceum (KRISS 1963). The maximal size of the bacteria was $1.48 \times 0.92 \mu$; the minimal size $0.46 \times 0.46 \mu$. These measurements were taken with a calibrated shearing ocular using hanging drops of inoculum, but they were not from the actual cultures used for the experiments; they thus give some indication of the particle size collected by the velum. A suspension of cells for feeding to the larvae was obtained by washing 3-5 ml glass-filtered sea water over the surface of a young slope culture. The concentration in the experiments was $10^{6}-10^{7} \mathrm{ml}$. Veligers of Nassarius reticulatus were exposed to each of the eight strains of bacteria for periods of up to $1 \mathrm{~h}$, and during this time the gut contents of some were examined under the phase-contrast microscope. Some of the remaining larvae were transferred to a suspension of Cricosphaera ap. carterae and the rest left in the bacterial suspension. For observations on growth 2 batches of 20 Nassarius reticulatus larvae were exposed to motile bacteria for $30 \mathrm{~min}$, transferred to fresh filtered sea water for $5 \mathrm{~min}$ and then into another experimental vessel with $C$. ap. carterae at a concentration of $4 \times 10^{4} \mathrm{cell} / \mathrm{s} / \mathrm{ml}$. They were left with the algal food 2.5 days when the feeding cycle was repeated. The growth of these larvae over a period of 10 days was compared with that of others fed only on the same concentration of $C$. ap. carterae during this period and with food and water renewed at 2.5 day intervals. All larvae for these experiments were from the same batch of eggs. After hatching they had been kept in glass-filtered sea water $48 \mathrm{~h}$ at $12^{\circ} \mathrm{C}$.

All strains of bacteria were eaten by the veligers and after 5 min a moderately dense collection was mixed with secretion in the stomach. They were sucked into the lobes of the digestive gland, especially the larger lobe, and taken by the ingesting cells. No bacterium was seen to be motile in the gut: they were passed along rapidly by the oesophageal cilia and into the whirling stomach contents. As compared with algal foods which must be broken mechanically before the digestive gland can deal with them, the ingestion of bacteria by the gland was rapid. It was not until the larvae were removed from the bacterial foods and fed on Cricosphaera ap. carterae that the ingesting cells were seen to be emitting bacterial waste; they soon became yellow with the algal pigments. After feeding on the plant cells $1.25 \mathrm{~h}$ there was faecal waste containing residues from both foods. Whole bacteria appeared to be in it, but changes in their structure revealed by the phase-contrast microscope suggested that something other than the mucous coat which envelops each cell may have been utilized by the larvae. The activity of the larvae was not impaired, but larvae not removed from bacterial food were unhealthy after 1.5 days. An examination of their digestive glands showed the ingesting cells packed with bacteria and apparently incapable of voiding them as though injured by their toxic metabolites.

The average growth in shell length of 40 veligers, which had been exposed to bacteria for 4 half-h periods during 10 days and otherwise fed on Cricosphaera ap. carterae, was $80 \mu$. For veligers fed on $C$. ap. carterae only it was $90 \mu$. Both batches of larvae remained healthy after the experiment. The results show that the occasional high intake of these bacteria is not injurious to the healthy veligers provided that an abundance of good food, moderately free from bacteria, is otherwise available. 


\section{DISCUSSION}

The factors influencing the value of algal species as food for gastropod larvae include the composition and texture of the cell wall as well as cell size and contents. The walls of algal cells are of varied composition and texture. There is no evidence that they are utilized by any prosobranch larva and their shattered remains can be found in the faeces; no fragment of wall has been seen in the cells of the digestive gland. The mechanical treatment the cells receive from the moment they enter the stomach weakens or disintegrates the walls so that cell contents are made accessible to the gastric juices. The resistance of cells with complete cellulose walls suggests the absence of a cellulase (Fretter \& Montgomery 1968). Thus Chlamydomonas parkeae is retained in the stomach of Crepidula fornicata and Nassarius reticulatus, but the digestive gland is not coloured with the algal pigment and cells pass into the intestine apparently unharmed. It was used only in growth experiments with $C$. fornicata. The slight growth which resulted may have been due to the digestion of the mucous coat surrounding each cell and bacteria and organic matter from the culture medium introduced with the algal cells. The cell contents of another chlorophycean, Brachiomonas submarina, were obtainable after considerable battering against the gastric shield. Utilization of this food was slow and poor growth resulted. On the contrary, the cellulose walls of Exuviaella baltica offer much less resistance since each is composed of 2 watch-glass shaped thecae which can be forced apart in about $10 \mathrm{~min}$ and soon after this the cell empties. Cells of the second species of this genus, E. pusilla, are emptied more slowly.

Cells of Monochrysis lutheri and Pyramimonas grossii fragment rapidly in the stomach, but because of their size and shape they provide a higher proportion of undigestible cell covering to utilizable inclusions. A workable stomachful is about 60 cells and from these the faecal waste is bulky. In healthy larvae this waste is flushed away by the flow of water through the mantle cavity which is maintained by the osphradial cilia. But, if larvae are less vigorous, excessive waste from high concentrations of food will accumulate near the anus. These faeces and also those resulting from a meal of the diatom Phaeodactylum tricornutum are frequently uncompacted and disintegrate as they are dropped. The spiny frustules of the diatom are discarded intact and some still have protoplasmic contents. The larvae are wasteful with this food: the cells are easily ingested and their presence in the stomach stimulates the muscular pulsations of the lobes of the digestive gland, but, perhaps because they irritate the gut, an undiluted meal of these cells, especially if they are large, acts as a purgative.

The best food, Cricosphaera ap. carterae, comprises large, almost spherical cells, their diameter being 10-18 $\mu$, and about 30 are found in a stomachful. They are battered vigorously, but the walls do not fragment. The flagella are soon lost, the calcite plates of the walls are forced apart as the protoplasm swells and within 15 min the plant pigments colour the digestive gland and some cells are empty. The emptied remains are retained in the stomach while other cells are digested. Undigested cells are rare in the faeces.

The ease with which the contents of algal cells are made available for digestion 
is important in a mixed diet. If cells of Cricosphaera ap, carterae are eaten with the easily fragmented cells of Monochrysis lutberi or Pyramimonas grossii, or even with cells of Olistbodiscus sp. or Exuviaella baltica which need a moderate mechanical force to weaken them, some Cricosphaera ap. carterae cells will leave the gut undigested. This is especially noticeable with the smaller cells which are so easily ingested. Their fragments buffer the walls of $C$. ap. carterae against the hurling action of the gastric cilia and the stomach is emptied before all the cells are digested. The stomach is emptied in response to a bulky accumulation of waste or the availability of more food. When Olisthodiscus sp. is eaten with $C$. ap. carterae its cell contents are the more easily available so that its toxic properties appear virtually unreduced.

Plant pigments as well as cell walls are waste to the veliger. All pigments are taken into the ingesting cells and later leave them, so they delay the cycle of events in the digestive gland. Parsons et al. (1961) have estimated indigestible matter of some algal species with respect to crude fibre, as $\%$ total carbohydrate, and pigment content as $\%$ dry weight. For Cricosphaera ap. carterae these are $1.7 \%$ and $1.1 \%$ respectively, for Monochrysis lutheri $3.6 \%$ and $0.8 \%$ and for Pbaeodactylum tricornutum $2.5 \%$ and $2.9 \%$. C. ap. carterae is moderately low in crude fibre and pigment, in agreement with the observation that little waste is produced, and Monocbrysis lutheri is high in crude fibre. However an unspecified species of Exuviaella baltica had $37.0 \%$ total carbohydrate as crude fibre. It would be of interest to know more about the 2 species of $E$. baltica which give such contrasting results in growth experiments with prosobranch veligers.

When different species of alga are grown under approximately similar conditions they tend to resemble each other in the relative amount of crude protein, fats and hydrolysable polysaccharide (Collyer \& FogG 1955). Some differences do exist between classes, but these are usually small compared with the differences exhibited by a single species during the course of its growth in culture (Fog 1955).

COWEy \& CORner (1966) and CHAU et al. (1967) have estimated the aminoacids for several species of unicellular algae including Plymouth cultures used in these experiments $(100,75,404,156,81,285$ and 239). COWEY \& CoRner point out the similarity between the aminomacid spectra of the algal species and suggest that differences in food value cannot be explained in terms of amino-acid composition. This is further supported by Droop (1966) working on the response of amoebae to different algal foods. Earlier work by COWEY \& CORNER (1962) demonstrates that the amino-acid composition of particulate matter in sea water, algal cells, Calanus and fish muscle are very similar, suggesting that protein of a certain amino-acid composition may be typical of food chains in the sea. In contrast to amino-acids the component fatty-acid composition of marine phytoplankton lacks uniformity. Chuecas \& RIEY (1969) have studied 27 species of marine phytoplankton and their results indicate that the assemblages of unsaturated acids vary widely from one organism to another.

The concentration of algal food producing the best growth of veligers in the laboratory is much higher than they would normally be exposed to in Plymouth Sound. Similarly WALNE (1965) quotes a considerable amount of field data which points to the fact that oyster larvae are often living at lower densities of algal cells than 
those giving best growth in the laboratory, and experiments by CusHING (1959) suggest such a discrepancy for Calanus. WALNE concludes that the organic detritus in the sea (CORner 1961) comprises part of the oysters' food. CowEY \& CoRner (1963) have shown that as far as amino-acids are concerned Calanus would gain no advantage nutritionally from a selection of algal cells in preference to the aminoacid containing fraction of particulate matter as a whole. Obviously the same must hold for prosobranch veligers which ingest any particle not too big for the velar cilia to manipulate and retain the organic ones in the stomach for digestion.

Species of algae differ considerably in food value, even those belonging to the same genus as has been shown in the present experiment for Exuviaella baltica and E. pusilla. Previously it has been demonstrated that Dunaliella euchlora is a very poor food for clam larvae and another species of this genus good (DAvis \& GuILlard 1958); Cosmarium impressulum and Scenedesmus spinosus are good for Dapbnia magna whilst $C$. tetraopbthalmum, $S$. aabuensis and $S$. quadricula are poor or mediocre (Lefèvre 1942, Provasoli et al.. 1959). Some of these differences may be associated with differences in micronutrients and vitamins. Deficiencies in some algal foods have been made good under experimental conditions. The life span of Daphnia magna fed on a diet of Chlamydomonas parkeae was tripled by the addition of $200 \mathrm{mg} / 1$ pantothenic acid and egg production increased tenfold (FRITSCH 1953). Similarly riboflavin (alone or in combination with calcium pantothenate), thiamine hydrochloride and pyridoxine hydrochloride significantly increased the rate of growth of veligers of Crassostrea virginica and Ostrea lurida (DAvis \& ChanLEY 1956). However, these vitamins had no effect on the growth rate of the larvae of Mercenaria mercenaria. The requirements of the different species of bivalve larvae might be expected to vary and those of the veligers of Crepidula fornicata and Nassarius reticulatus even more so. It has been shown for C. fornicata that Exuviaella baltica approached Cricosphaera ap. carterae in nutritive value, but was a poor food for $N$. reticulatus. The adult $C$. fornicata is a microphagous feeder and the adult $N$. reticulatus essentially a carrion feeder and it is surprising that $C$. ap. carterae proved a good food for both, even up to the time of metamorphosis. $C$. fornicata veligers given only this food were ready to metamorphose after 4-6 weeks and $N$. reticulatus after 8 weeks.

A study of Olistbodiscus sp. which is toxic to these and other prosobranch veligers reveals a low lipid and carbohydrate content (RICKETTs 1966) and a high concentration of acid-soluble phosphorus compounds which may reflect an unidentified storage product. Only $64 \%$ of its total dry weight has been accounted for in terms of known substances. BIDwELL (1957) has found that the main storage product of photosynthesis is $d$-mannitol. Although even young cultures of this food are lethal to both young and old veligers of prosobranchs, larvae of Sabellaria alveolata are apparently unaffected by the alga. The largest larvae of $S$. alveolata reared in some experiments were those which in their older stages were given Olistbodiscus sp. alone or with another flagellate (WILSON 1968). 


\section{SUMMARY}

1. Larvae of Crepidula fornicata (L.) and Nassarius reticulatus (L.) were used for experiments. The conditions under which they thrived proved successful for veligers of other species.

2. They were kept in glass-filtered sea water (pore size $3.0 \mu$ ) in acid-clean glass containers, provided with algal foods and handled carefully by means of a pipette. Trapping larvae in a coarse filter as a means of transferring them from one vessel to another was injurious.

3. Shell length was used to estimate growth.

4. The growth of 20 veligers in $30 \mathrm{ml}$ sea water (depth $8 \mathrm{~cm}$ ) was compared with that of 333 veligers in $500 \mathrm{ml}$ (depth $9 \mathrm{~cm}$ ). Growth in the larger volume was better, but in all cases the differences were not significant at the $10 \%$ level.

5. Growth rate is influenced by light intensity. For comparing the value of different foods experiments were carried out under a constant intensity of 155 lux at the water surface. In the dark, mortality of algal cells stimulates growth of bacteria.

6. The water temperature was maintained at $12^{\circ} \mathrm{C}$. Low temperatures, even $8^{\circ} \mathrm{C}$, reduce the activity of veligers of Crepidula fornicata and Nassarins reticulatus; high temperatures favour bacterial growth.

7. The growth of recently hatched veligers feeding on one of 10 species of unicellular algae and on some mixtures of these was recorded for 2 (C. fornicata) or $3(N$. reticulatus) breeding seasons. Food was given at different concentrations $\left(2 \times 10^{3}\right.$, $20 \times 10^{3}, 40 \times 10^{3} \mathrm{cell} / \mathrm{s} / \mathrm{ml}$ ) which were calculated from haemocytometer counts of the stock cultures, though this gives only an approximate value. Experiments lasted up to 4.5 weeks and a few for a longer period.

8. Cricospbaera ap. carterae and Exuviaella baltica were the best foods for Crepidula fornicata, especially at higher concentrations, and larvae were ready to metamorphose in 40 days or less. C. ap. carterae and Dunaliella primolecta were good for Nassarius reticulatus, especially the former, and E. baltica consistently poorer.

9. Monochrysis lutheri and Pyramimonas grossii were moderately good foods, but with these none of the larvae metamorphosed. When fed to Crepidula fornicata at high concentrations $\left(80 \times 10^{3}, 120 \times 10^{3} \mathrm{cells} / \mathrm{ml}\right)$ growth of the former approached that with Cricosphaera ap. carterae whilst with the latter growth decreased with increased concentration. The food value of Pbaeodactylum tricornutum is lower; the large frustules irritate the gut and act as a purgative.

10. Chlamydomonas parkeae, Brachiomonas submarina, Exuviaella pusilla and Olisthodiscus sp. are poor foods; the last two are toxic.

11. When the food was 2 species of alga mixed in equal proportions the good value of Cricosphaera ap. carterae was still evident. Examination of the stomach contents showed that the larvae were not feeding selectively on this alga. When the second alga was one with smaller cells (Monochrysis lutheri or Pyramimonas grossii) these were ingested in greater numbers in accordance with the ease with which the velar cilia manipulated them.

12. Algal cells are subjected to mechanical treatment in the stomach; their walls may 
be shattered but no fragment has been seen in the cells of the digestive gland. The resistance of cells with complete cellulose walls suggests the absence of a cellulase.

13. With some algal foods (species of Monochrysis, Pyramimonas, Phaeodactylum) the walls produce a high proporrion of faecal waste which, in less vigorous larvae, may clog the exhalant passage of the mantle cavity.

14. Plant pigments are egested by the veliger. They are intimately linked with food, taken into ingesting cells of the digestive gland and later excreted. They thus delay the cycle of events in the gland.

15. Differences in food value of the various algae may be due to differences in micronutrients and vitamins essential to growth. The fact that one species of alga may produce good growth in one species of veliger and not another must reflect either differences in requirements or in assimilation of the food.

16. Prosobranch veligers are found in numbers well below the compensation depth as well as in other areas where the density of algal cells is low. It is suggested that organic detritus in the sea is an important item of food.

Acknowledgements. This work was carried out at the Plymouth Laboratory and was supported by a grant from the Science Research Council. We thank Dr. M. PARkE who supplied the algal cultures and gave valuable advice, the crews and staff of the Marine Biological Association, Plymouth, and, in particular, the Director, Dr. J. E. SMITH, F.R.S., for providing space and facilities. One of us (M.C.P.) wishes to thank the British Association for the use of their table at the Laboratory. We are also indebted to Dr. M. Rhodes and Mr. D. Wynn-Wirliams for supplying the cultures of bacteria and the information concerning them.

\section{LITERATURE CITED}

Armstrong, F. A. J. \& Butler, E. I., 1960a. Chemical changes in sea water off Plymouth during 1958. J. mar. biol. Ass. U.K. 39, 299-302.

- - 1960b. Chemical changes in sea water off Plymouth during 1959. J. mar. biol. Ass. U.K. 39, 525-528.

- - 1962. Chemical changes in sea water off Plymouth during 1960. J. mar. biol. Ass. U.K. 42, 253-258.

- - 1963. Chemical changes in sea water off Plymouth in 1961. J. mar. biol. Ass. U.K. $43,75-78$.

BAINBRIDGE, R., 1957. The size, shape and density of marine phytoplankton concentrations. Biol. Rev. 32, 91-115.

Bidwell, R. G. S., 1957. Photosynthesis and metabolism of marine algae. I. Photosynthesis of two marine flagellates compared with Chlorella. Can. J. Bot. 55, 945-950.

Bone, Q., 1961. The organization of the atrial nervous system of Amphioxus (Branchiostoma lanceolatum Pallas). Phil. Trans. R. Soc. (B) 243, 241-269.

Chau, Y. K., Chuecas, L. \& Riley, J. P., 1967. The component combined amino acids of some marine phytoplankton species. J. mar. biol. Ass. U.K. 47, 543-554.

ChIPPERfield, P. N. J., 1951. The breeding of Crepidula fornicata (L.) in the river Blackwater, Essex. J. mar. biol. Ass. U.K. 30, 49-71.

Chuecas, L. \& Riley, J. P., 1969. Component fatty acids of the total lipids of some marine phytoplankton. J. mar. biol. Ass. U.K. 49, 97-116.

COllyeR, D. M. \& FogG, G. E., 1955. Studies on fat accumulation by algae. J. exp. Bot. 6, 256-275. 
Corner, E. D. S., 1961. On the nutrition and metabolism of zooplankton. I. Preliminary observations on the feeding of the marine copepod, Calanus belgolandicus (Claus). J. mar. biol. Ass. U.K. 41, 5-16.

Cowey, C. B. \& Corner, E. D. S., 1962. The amino-acid composition of Calanus finmarchicus (Claus) in relation to that of its food. Rapp. P.-v. Réun. Cons. perm. int. Explor. Mer 153, 124-128.

- - 1963. On the nutrition and metabolism of zooplankton. II. The relationship between the marine copepod Calanus belgolandicus and particulate material in Plymouth sea water, in terms of amino-acid composition. J. mar. biol. Ass. U.K. 43, 495-511.

- - 1966. The amino-acid composition of certain unicellular algae and of the faecal pellets produced by Calanus finmarcbicus when feeding on them. In: Some contemporary studies in marine science. Ed. by H. Barnes. Allen \& Unwin, London, 225-231.

Cushing, D. H., 1959. On the nature of production in the sea. Fishery Invest., Lond. (Ser. 2) $22,1-40$.

Daves, H. C., 1953. On food and feeding of larvae of the American oyster, C. virginica. Biol. Bull. mar. biol. Lab., Woods Hole 104, 334-350.

- \& Chanley, P. E., 1956. Effects of some dissolved substances on bivalve larvae. Proc. natn. Shellfish. Ass. 46, 59-74.

- \& GuIllard, R. R., 1958. Relative value of ten genera of micro-organisms as food for oyster and clam larvae. Fishery Bull. Fish Wildl. Serv. U.S. 58, 293-304.

Droop, M. R., 1966. The role of algae in the nutrition of Heteramoeba clara Droop, with notes on Oxyrrhis marina Dujardin and Pbilodina roseola EhrenBerg. In: Some contemporary studies in marine science. Ed. by H. Barnes. Allen \& Unwin, London, 269-282.

FoGG, G. E., 1965. Algal cultures and phytoplankton ecology. Athlone press, London, 126 pp.

FretTer, V., 1967. The prosobranch veliger. Proc. malac. Soc. Lond. 37, 357-366.

- \& Montgomery, M. C., 1968. The treatment of food by prosobranch veligers. J. mar. biol. Ass. U.K. 48, 499-520.

FRrTSCH, R. H., 1953. Die Lebensdauer von Daphnia spec. bei verschiedener Ernährung, besonders bei Zugabe von Pantothensäure. Z. wiss. Zool. 157, 35-56.

Guillard, R. R. L., 1959. Further evidence of the destruction of bivalve larvae by bacteria. Biol. Bull. mar. biol. Lab., Woods Hole 117, 258-266.

Imai, T. \& Hatanaka, M., 1949. On the artificial propagation of the Japanese common oyster, Ostrea gigas Thun. by non-coloured naked flagellates. Bull. Inst. agric. Res. Toboku Univ. 1, 33-46.

KorRingA, P., 1951. Difficulties encountered in tank-breeding of oysters (Ostrea edulis). Rapp. P. v. Réun. Cons. perm. int. Explor. Mer 128, 35-38.

Kriss, A. E., 1963. Marine microbiology. Transl. from the Russian. Oliver \& Boyd, Edinburgh, $536 \mathrm{pp}$.

Lebour, M. V., 1931. The larval stages of Nassarius reticulatus and N. incrassatus. J. mar. biol. Ass. U.K. 17, 797-816.

Lefìvre, M., 1942. L'utilisation des algues d'eau douce par les cladocères. Bull. biol. Fr. Belg. 76, 250-276.

Martindale, W., 1967. Penicillins and other antibiotics. In: Todd, R. G.: Extra Pharmacopoeia. The Pharmaceutical Press, London, $1804 \mathrm{pp}$.

Parsons, T. R., Stephens, K. \& Strickland, J. D. H., 1961. On the chemical composition of eleven species of marine phytoplankters. J. Fish. Res. Bd Can. 18, 1001-1016.

Paulson, T. C. \& Scheltema, R. S., 1968. Selective feeding on algal cells by the veliger larvae of Nassarius obsoletus (Gastropoda, Prosobranchia). Biol. Bull. mar. biol. Lab., Woods Hole 134, 481-489.

Provasoli, L., Shivaiski, K. \& Lance, J. R., 1959. Nutritional idiosyncrasies of Artemia and Tigriopus in monoxenic culture. Ann. N. Y. Acad. Sci. 77, 250-261.

Reeve, M. R., 1963. The filter-feeding of Artemia, I, II, III. J. exp. Biol. 40, 195-221.

RicketTs, T. R., 1966. On the chemical composition of some unicellular algae. Phytochemistry $5,67-76$. 
Scheltema, R. S., 1962. Pelagic larvae of New England intertidal gastropods.. I. Nassarius obsoletus $\mathrm{S}_{\mathrm{AY}}$ and Nassarius vibex SAY. Trans. Am. microsc. Soc. 81, 1-11.

- 1967. The relationship of temperature to the larval development of Nassarius obsoletus (Gastropoda). Biol. Bull. mar. biol. Lab., Woods Hole 132, 253-265.

SHEWAN, J. M., 1963. The differentiation of certain genera of gram negative bacteria frequently encountered in marine environments. In: Symposium on marine microbiology. Ed. by C. H. Oppenheimer. C. C. Thomas, Springfield, Ill., 499-521.

Walne, P. R., 1956a. Bacteria in experiments on rearing oyster larvae. Nature, Lond. 178, 91.

- 1956b. Experimental rearing of larvae of Ostrea edulis L. in the laboratory. Fishery Invest., Lond. (Ser. 2) 20 (9), 1-23.

- 1958. The importance of bacteria in laboratory experiments on rearing the larvae of Ostrea edulis (L.) J. mar. biol. Ass. U.K. 37, 415-425.

- 1963. Observations on the food value of seven species of algae to the larvae of Ostrea edulis. 1. Feeding experiments. J. mar. biol. Ass. U.K. 43, 767-784.

- 1965. Observations on the influence of food supply and temperature on the feeding and growth of the larvae of Ostrea edulis L. Fishery Invest., Lond. (Ser. 2) 24 (1), 1-45.

WiLson, D. P., 1968. Some aspects of the development of eggs and larvae of Sabellaria alveolata (L.). J. mar. biol. Ass. U.K. 48, 367-386.

First author's address: Margaret C. Pilkington

Portobello Biological Station

New Zealand 